\title{
Nucleolar organiser regions in normal, cirrhotic, and carcinomatous livers
}

\author{
J CROCKER, JULIE MCGOVERN
}

From the Department of Histopathology, East Birmingham Hospital, Bordesley Green East, Birmingham

SUMMARY A series of 54 liver biopsy specimens was studied by means of the argyrophil (AgNOR) technique for nucleolar organiser region (NOR)-associated proteins. These included normal livers and livers affected by chronic active hepatitis, cirrhosis, hepatocellular carcinoma and adenoma. Four of the cases of cirrhosis showed liver cell dysplasia. The mean numbers of NOR sites in normal, cirrhotic, and carcinomatous livers were significantly different: adenoma had similar mean counts to those in chronic active hepatitis (CAH). There was no overlap between the ranges of NOR counts in normal, cirrhotic, and malignant liver specimens. Where cirrhosis and hepatocellular carcinoma were present in the same specimen, the AgNOR counts were higher in the carcinomatous than cirrhotic areas. To investigate the prospective value of the method a further seven biopsy specimens were studied; in these it had not been possible to decide on a diagnosis between normality and cirrhosis or cirrhosis and hepatocellular carcinoma. In all seven specimens a repeat biopsy or necropsy gave results as predicted by AgNOR staining. It is therefore proposed that quantitation of staining for NOR-associated proteins is a diagnostically useful method in liver disease.

The diagnostic value of counting nucleolar organiser regions (NORs) in cases of malignancy has been emphasised recently. ${ }^{12}$ The demonstration of NORs by virtue of the argyrophilia of their associated proteins (NORAPs) is simple, rapid, and reproducible and has afforded useful data in a series of neoplasms, including those of the lymphoid system, ${ }^{3}$. pleural mesothelium, ${ }^{4}$ breast, ${ }^{5}$ small round cell tumours ${ }^{6}$ and fibroblastic tumours of childhood, ${ }^{7}$ melanocytic tumours, ${ }^{8}$ and other skin neoplasms. ${ }^{9}$

In liver disease the distinction between normality, hepatitis, cirrhosis and primary malignancy may at times be difficult. As the cirrhotic process is one of increased cellular activity and because NOR numbers reflect such a process, we examined the NOR count in a series of liver specimens of known pathology, including established cirrhosis, chronic active hepatitis, and hepatocellular carcinoma, and compared these with biopsy specimens of normal livers. Furthermore, a prospective series of equivocal biopsy specimens was examined and the numbers of NORs related to the histological outcome in subsequent material.

\section{Material and methods}

LIVER BIOPSY SPECIMENS

Fifty four specimens of known liver pathology were Accepted for publication 21 April 1988 examined initially. All were needle biopsies and comprised 10 specimens of normal liver, 10 with chronic active hepatitis (CAH), 10 with cirrhosis(seven established and three in the active phase), and 10 with hepatocellular carcinoma (three "scirrhous", two "pseudoglandular," and five "trabecular" types). A further five specimens included concomitant cirrhosis and hepatocellular carcinoma, and four showed liver cell dysplasia in cirrhosis with increased mitoses and nuclear pleomorphism. Finally, five specimens were of liver cell adenoma (table 1). A further seven specimens of equivocal histology were studied. In two of these it was uncertain whether the liver was normal or cirrhotic and in five whether it was cirrhotic or malignant (table 2).

\section{AGNOR TECHNIQUE AND ENUMERATION}

PROCEDURE

The one step argyrophil method was used as described previously. ${ }^{3}$ This was run at room temperature in the dark for 30-35 minutes. The AgNOR sites were counted in 200 randomly selected hepatocytes, using a $\times 100$ oil-immersion objective and an eyepiece graticule to prevent recounting. Bile ductular, vascular, inflammatory and Kupffer cells were not included in the enumeration procedure. In the cases of cirrhosis and hepatocellular carcinoma 200 hepatocytes were counted from both areas. In the case of bi- or multinucleate cells the numbers of NORs were 
Table 1 Mean numbers of nuclear AgNOR sites for each specimen

\begin{tabular}{|c|c|c|c|c|c|c|c|c|}
\hline \multirow[b]{2}{*}{$\begin{array}{l}\text { Case } \\
\text { No }\end{array}$} & \multirow[b]{2}{*}{$\begin{array}{l}\text { Normal } \\
\text { liver }\end{array}$} & \multirow{2}{*}{$\begin{array}{l}\text { Chronic } \\
\text { active } \\
\text { hepatitis }\end{array}$} & \multirow[b]{2}{*}{ Cirrhosis } & \multirow[b]{2}{*}{ Adenomas } & \multirow[b]{2}{*}{$\begin{array}{l}\text { Hepatocellular } \\
\text { carcinoma }\end{array}$} & \multicolumn{2}{|l|}{ Mixed } & \multirow{2}{*}{$\begin{array}{l}\text { Cirrhosis } \\
\text { with } \\
\text { dysplasia }\end{array}$} \\
\hline & & & & & & Cirrhosis & $\begin{array}{l}\text { Hepatocellular } \\
\text { carcinoma }\end{array}$ & \\
\hline $\begin{array}{r}1 \\
2 \\
3 \\
4 \\
5 \\
6 \\
7 \\
8 \\
9 \\
10\end{array}$ & $\begin{array}{l}1.5 \\
1.6 \\
1.6 \\
1.8 \\
1.9 \\
2.0 \\
2.0 \\
2.1 \\
2.1 \\
2.2\end{array}$ & $\begin{array}{l}2.8 \\
1.8 \\
1.9 \\
1.9 \\
2.0 \\
2.1 \\
2.2 \\
2.5 \\
2.5 \\
2.5\end{array}$ & $\begin{array}{l}2.8 \\
2.8 \\
2.9 \\
3.1 \\
3.2 \\
3.2 \\
3.2 \\
3.6 \\
3.6 \\
3.7\end{array}$ & $\begin{array}{l}2 \cdot 2 \\
2 \cdot 2 \\
2 \cdot 3 \\
2 \cdot 4 \\
2 \cdot 4 \\
0 \\
0 \\
0 \\
0 \\
0\end{array}$ & $\begin{array}{r}5.6 \\
5.8 \\
6.1 \\
6.3 \\
6.7 \\
7.1 \\
7.2 \\
8.5 \\
10.4 \\
15.1\end{array}$ & $\begin{array}{l}2 \cdot 7 \\
3 \cdot 2 \\
3 \cdot 5 \\
3 \cdot 5 \\
3 \cdot 7 \\
0 \\
0 \\
0 \\
0 \\
0\end{array}$ & $\begin{array}{c}6 \cdot 2 \\
6 \cdot 3 \\
7 \cdot 0 \\
7 \cdot 3 \\
10.5 \\
0 \\
0 \\
0 \\
0 \\
0\end{array}$ & $\begin{array}{l}3.6 \\
4.2 \\
4.2 \\
5.9 \\
0 \\
0 \\
0 \\
0 \\
0 \\
0\end{array}$ \\
\hline $\begin{array}{l}\text { Mean } \\
\text { SD } \\
\text { SEM }\end{array}$ & $\begin{array}{l}1.88 \\
0.244 \\
0.074\end{array}$ & $\begin{array}{l}2.12 \\
0.29 \\
0.088\end{array}$ & $\begin{array}{l}3 \cdot 21 \\
0.33 \\
0.1\end{array}$ & $\begin{array}{l}2 \cdot 3 \\
0 \cdot 1 \\
0.04\end{array}$ & $\begin{array}{l}7.88 \\
2.9 \\
0.88\end{array}$ & $\begin{array}{l}3 \cdot 32 \\
0.39 \\
0 \cdot 17\end{array}$ & $\begin{array}{l}7.46 \\
1.76 \\
0.78\end{array}$ & $\begin{array}{l}4.48 \\
0.99 \\
0.495\end{array}$ \\
\hline
\end{tabular}

counted in each nucleus. The significance of results was assessed by the Mann-Whitney U test. Data were analysed by means of the First Statistical Computer Program (Serious Statistical Software, Lynwood, South Wirral, England).

\section{Results}

AgNOR sites were strongly stained as black nuclear dots of varying sizes. When only one or two AgNORs were present they were usually about $1-2 \mu$ m diameter; when multiple sites were stained they were smaller and varied in size, from 0.5 to $1 \mu \mathrm{m}$ diameter. There was no significant difference between the values for normal livers (mean 1.88 AgNOR/nucleus; median 1.95; SD $0 \cdot 24 ; 95 \%$ confidence interval $0 \cdot 78-2 \cdot 12$ ), adenomas

Table 2 Outcome of a series of seven biopsy specimens of equivocal histology, where AgNOR counts were performed

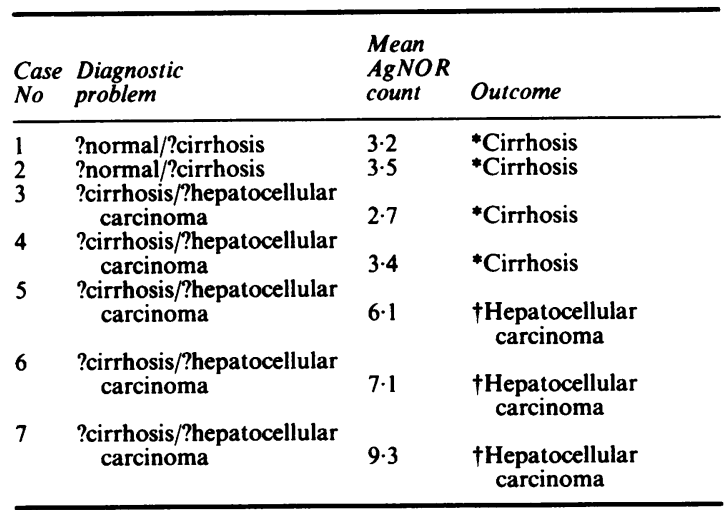

*Pooled mean for cirrhotic specimens $=3 \cdot 2($ SD 0.36)

*Pooled median for cirrhotic specimens $=3.41$

tPooled mean for $\mathrm{HC}$ specimens $=7.5($ SD 1.64)

tPooled median for $\mathrm{HC}$ specimens $=7.83$ (mean 2.3; median 2.3; SD 0 1 ; $95 \%$ CI $2 \cdot 21-2 \cdot 40$ ), and chronic active hepatitis (mean 2.12; median 2.15; SD $0.29 ; 95 \%$ CI $1.94-2 \cdot 34)(U=24$, overall; $p=$ not significant). This group, however, was significantly different from cirrhotics (mean 3.21 ; median 3.03 ; SD $0.33 ; 95 \%$ CI 2.79-3.25) ( $U=0 ; p \ll 0.001)$ which in turn were also significantly different from the group

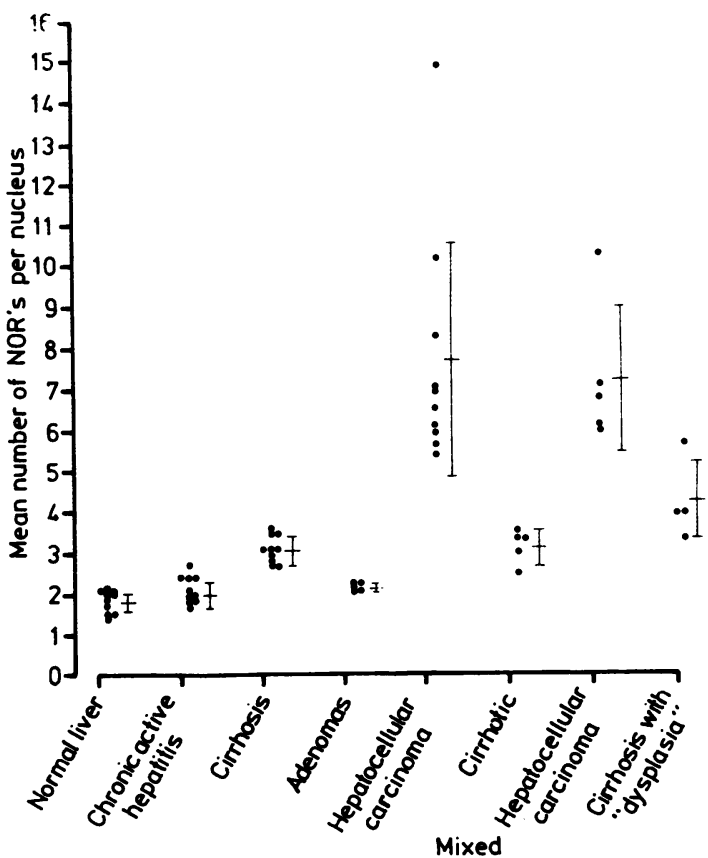

Fig 1 "Scattergram" of AgNOR numbers in the hepatic specimens examined. There is separation of the values for normality, cirrhosis, and hepatocellular carcinoma. Liver cell "dysplasia" values lie intermediate between cirrhosis and carcinoma. 


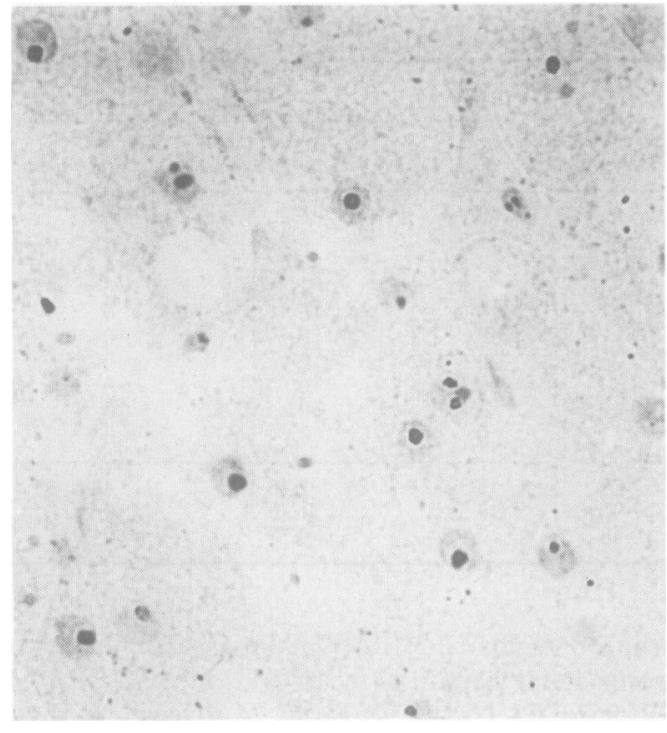

Fig 2 AgNOR staining of normal liver. Only one or two dots are seen in each nucleus.

with hepatocellular carcinoma (mean 7.88; median 6.90; SD 2.9; 95\% CI 4.90-8.86) $(\mathrm{U}=0 ; \mathrm{p} \ll 0.001)$. In the specimens containing established cirrhosis with hepatocellular carcinoma, the counts in the two regions differed greatly (cirrhotic areas: 3.32 mean AgNORs/nucleus; median 3.25; SD 0.39; $95 \%$ CI 2.80-3.69); hepatocellular carcinoma areas: 7.46 mean

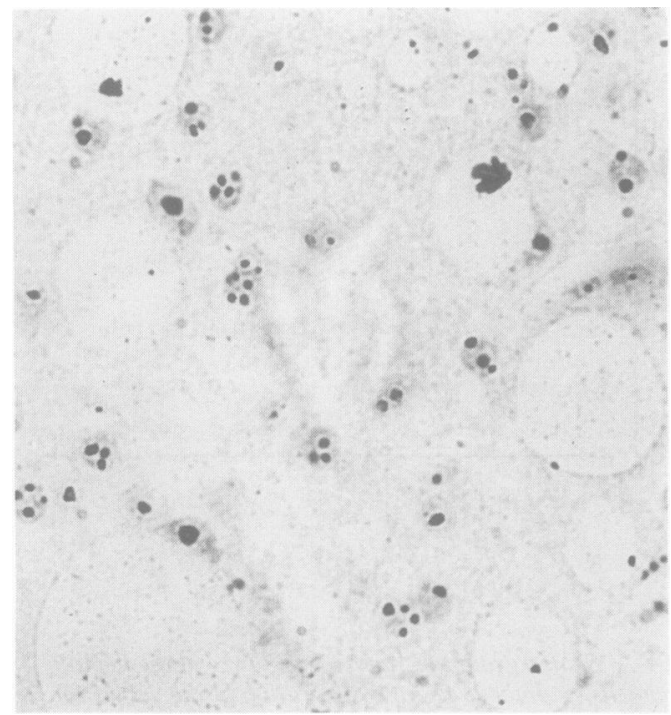

Fig 3 AgNOR staining of cirrhotic liver. Most nuclei contain three to four dots.

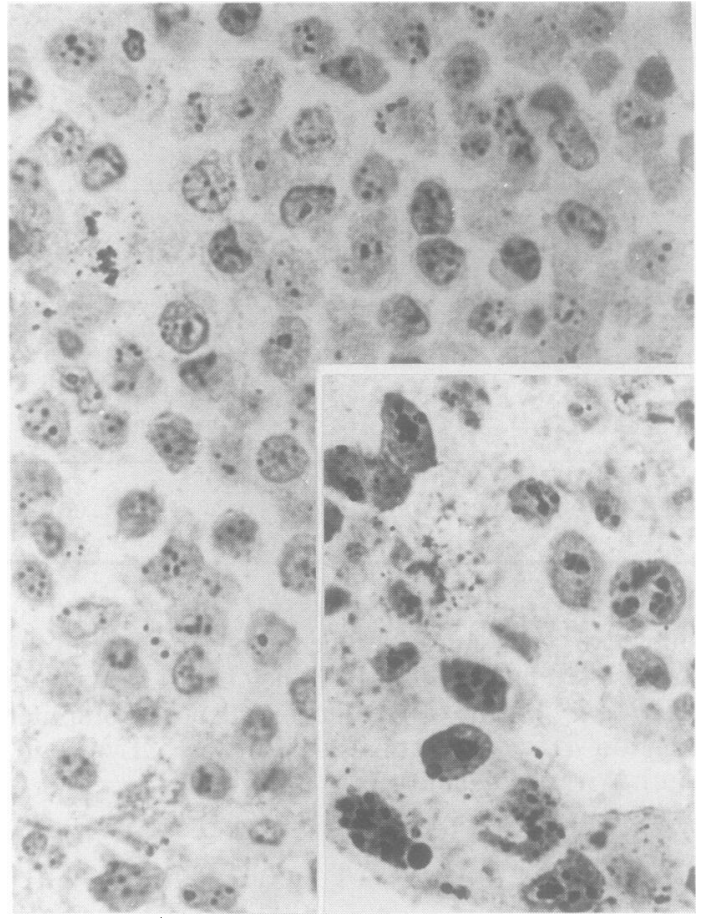

Fig 4 Solid area from a trabecular hepatocellular carcinoma. Most nuclei contain multiple dots. Inset: higher power view of the same neoplasm, with numerous AgNOR sites per nuclear profile.

AgNORs/nucleus; median 7.0; SD 1.76; 95\% CI 5.19.0) $(U=0 ; p \ll 0.001)$. Intermediate values were seen in the four cases of cirrhosis judged to possess liver cell dysplasia (mean 4.48 AgNORs/nucleus; median 4.20; SD $0.99 ; 95 \%$ CI 2.77-5.5) $(U=2 ;$ p $<0.05$ compared with hepatocellular carcinoma; $U=2$; p $<0.05$ compared with cirrhosis) (figs $1-4$ ).

In the series of specimens of uncertain histology four had "low" AgNOR counts (range 2.7-3.5/ nucleus; mean 3.2; median 3.41; SD 0.36; $95 \%$ CI 1.01-7.84) and three had "high" values (range 6.1-9.3/ nucleus; mean 7.5; median 7.83; SD 1.64 ; $95 \%$ CI 2.79-12.83). In two of the first four specimens the diagnosis lay between normality and cirrhosis and in the second pair between cirrhosis and hepatocellular carcinoma; but the values were all in the cirrhotic range. On rebiopsy (within two weeks) the diagnosis proved to be cirrhosis in all four specimens. In the remaining three cases the diagnostic uncertainty related to cirrhosis $v$ hepatocellular carcinoma; the range of AgNOR counts was within the hepatocellular carcinoma range in all three and, indeed, this proved to be the correct diagnosis on rebiopsy (and, in two cases, necropsy) in each of the three. As in previous 
studies reproducibility of counts was 3-5\% (intraobserver and interobserver).

\section{Discussion}

NORs have recently found several applications in diagnostic and research histopathology. ${ }^{12}$ These structures, which may be seen in $D$ and $G$ group acrocentric chromosomes $13,14,15,21$ and 22 in man, in metaphase, and as fibrillar centres in interphase nuclei, are loops of ribosomal DNA. ${ }^{1-10}$ Their sizes and numbers vary with the degree of differentiation in cell lines in vitro, as shown for example, in human promyelocytic leukaemic (HL60) cells, where induction of differentiation leads to diminution of NOR numbers. " Conversely, in phytohaemagglutinin-stimulated "blast transformation of human peripheral blood lymphocytes," NOR numbers increase. ${ }^{12}$ Indeed, in many instances the numbers of NORs are increased in malignant cells by comparison with their normal counterparts. ${ }^{1314}$ The reason for this phenomenon is uncertain. It could be related to increased ploidy, but DNA flow cytometry of non-Hodgkin's lymphomas has produced no evidence for this. ${ }^{15}$

Another possibility is that NOR numbers in interphase are part of a fundamental process related to cell proliferation and transformation; certainly, in human lymphomas, there is a highly significant association and correlation between NOR counts and the numbers of cells labelled with the monoclonal antibody Ki67 which seems to be a marker of proliferating cells. ${ }^{16}$ Other possible determinants of the numbers of NORs in a particular cell include rDNA gene amplification phenomena, the stage of the cell cycle, and circadian rhythms and age, whose effect is as yet uncertain. ${ }^{2}$

It has been shown, however, that the enumeration of silver stained interphase NORs in a variety of human tissues may provide valuable, often diagnostic, data. NOR counts distinguish between high and low grade non-Hodgkin's lymphomas, ${ }^{3}$ malignant melanomas and melanocytic naevi, ${ }^{8}$ skin adnexal tumours, "oat cells" and lymphocytes, ${ }^{17}$ benign and malignant pleural mesothelial cells, ${ }^{4}$ types of small round cell tumours ${ }^{6}$ and benign and malignant fibroblastic lesions ${ }^{7}$ of childhood, benign and invasive transitional cell tumours of the nose, ${ }^{18}$ and benign and malignant salivary gland neoplasms. ${ }^{19}$ Other tissues, notably those of endocrine type and some surface epithelia, yield less useful distinctions between hyperplastic and benign and malignant neoplastic lesions. ${ }^{25}$ The reason for this is obscure but could, in part, result from continuing stimulation or proliferation of normal cells, at least in some endocrine organs, with gene amplification. ${ }^{20}$

In this study we have shown that the simple, reproducible AgNOR method can be applied to problems of liver disease. It may often be difficult in small needle biopsy specimens to distinguish between normality or cirrhosis (especially of the macronodular variety), or between cirrhosis and hepatocellular carcinoma when the latter is exceptionally well differentiated. The ranges and pooled means of AgNOR counts for these lesions are widely separated and would enable the distinction to be made readily, even in small specimens. The same is true for adenomas and hepatocellular carcinoma, where histological distinction may be difficult. The increased numbers of AgNORs in the cells of cirrhosis presumably relate to increased cell turnover in regeneration nodules, but these numbers did not approach those observed in hepatocellular carcinoma, where cell proliferation is presumably even more pronounced.

It is also of interest that in cirrhosis with dysplasia the AgNOR numbers lay between those in cirrhosis alone and hepatocellular carcinoma. This may represent rDNA gene amplification in premalignancy. In Novikoff hepatoma cells in vitro, an excess of abnormal NOR complexes has been reported over normal or regenerating liver cells. ${ }^{14}$ Furthermore, the AgNOR counts in seven biopsy specimens of equivocal pathology were able to predict the type of disease, as confirmed by repeat biopsy (or necropsy) within a short time from the initial biopsy.

These findings underline the usefulness of this technique in diagnostic histology. A recent brief review questioned the technical ease of the method and its reproducibility. ${ }^{21}$ There have, in fact, been no difficulties in attaining intra- and interobserver errors of only 1-5\% in AgNOR enumeration, as recorded in several recent papers. ${ }^{2467-9}$ Furthermore, painstaking attention to water purity has solved any problems which have occurred in our laboratories (and in those seeking our assistance).

We are grateful to Mrs Ruth Fry for word processing and Mrs Pamela Jackson for graphics.

\section{References}

1 Editorial. NORs-a new method for the pathologist. Lancet 1987;i:1413-4.

2 Crocker J. Nucleolar organizer regions. In: Underwood JCE, ed. Current topics in pathology. Heidelberg: Springer Verlag: (in press).

3 Crocker J, Nar P. Nucleolar organizer regions in lymphomas. J Pathol 1987;151:111-8.

4 Ayres JG, Crocker J, Skilbeck NQ. Differentiation of malignant from normal and reactive mesothelial cells using the argyrophil method for nucleolar organizer regions. Thorax 1988;43:36670.

5 Smith R, Crocker J. Evaluation of nucleolar organizer regionassociated proteins in breast malignancy. Histopathology 1988;12:113-24. 
6 Egan MJ, Raafat F, Crocker J, Smith K. Nucleolar organizer regions in small cell tumours of childhood. $J$ Pathol 1987;153:275-80.

7 Egan MJ, Raafat F, Crocker J, Smith K. Nucleolar organizer regions in fibrous proliferations of childhood and infantile fibrosarcoma. J Clin Pathol 1988;41:31-3.

8 Crocker J, Skilbeck NQ. Nucleolar organizer region associated proteins in cutaneous melanocytic lesions: a quantitative study. J Clin Pathol 1987;40:885-9.

9 Egan MJ, Crocker J. Nucleolar organizer regions in cutaneous tumours. J Pathol 1988;154:247-53.

10 Goessens S, Thiry M, Lepoint A. Relations between nucleoli and nucleolus-organizing regions during the cell cycle. In: Stahl A, Lucini JM, Vagner-Capodano AM, eds. Chromosomes today. Vol 9. London: George Allen \& Unwin, 1987;261-74.

11 Reeves BR, Casey S, Honeycombe JR, Smith S. Correlation of differentiation state and silver staining of nucleolar organizers in the promyelocytic cell line HL-60. Cancer Genet Cytogenet 1984;13:159-66.

12 Field DH, Fitzgerald PH, Sin FYT. Nucleolar silver-staining patterns related to cell cycle phase and cell generation of PHAstimulated human lymphocytes. Cytobios 1984;41:23-33.

13 Crossen PE, Godwin JM. Rearrangement and possible amplification of the ribosomal RNA gene sites in the human myelogenous leukaemia cell line K 562. Cancer Genet Cytogenet 1985;8:27-30.
14 Busch H, Daskal Y, Gyorkey F, Smetana K. Silver staining of nucleolar granules in tumor cells. Cancer Res 1979;39:857-63.

15 Crocker J, Macartney JC, Smith PJ. Correlation between DNA flow cytometric and nucleolar organizer region data in nonHodgkin's lymphomas. J Pathol 1988;154:151-6.

16 Hall PA, Crocker J, Watts A, Stansfeld AG. A comparison of nucleolar organizer region staining and Ki67 immunostaining in non-Hodgkin's lymphoma. Histopathology 1988;12:373-82.

17 Crocker J, Ayres JG, McGovern J. Nucleolar organizer regions in small cell carcinoma of the bronchus. Thorax 1987;42:972-5.

18 Egan MJ, Ramsden K, Crocker J. Nucleolar organizer regions in inverted transitional cell papillomas of nose. Histopathology 1988; 12: (in press).

19 Morgan DW, Crocker J, Watts A, Shenoi PM. Salivary gland tumours studied by means of the AgNOR techniques. Histopathology 1988;12: (in press).

20 DeCapoa A, Baldini A, Marleykaj P, et al. Hormone-modulated rRNA gene activity is visualised by selective staining of the NORS. Cell Biol Int Rep 1985;9:791-6.

21 Walker RA. Commentary: The histopathological evaluation of nucleolar organizer region proteins. Histopathology 1988; 12:221-2.

Requests for reprints to: Dr J Crocker, Department of Histopathology, East Birmingham Hospital, Bordesley Green East, Birmingham B9 5ST, England. 